\title{
The use of a semi-synthetic liquid diet for the supply of ethanol to rats and its effect on lysosomal enzyme activities in the liver*
}

\author{
By L. PILSTRÖM, E. FELLENIUS AND K.-H. KIESSLING \\ Alcohol Research Group, Swedish Medical Research Council, \\ Institute of Zoophysiology, University of Uppsala, Uppsala, Sweden
}

(Received 6 fuly 1972-Accepted 2 October 1972)

\begin{abstract}
I. A liquid diet is described for the supply of ethanol to rats with a constant proportion of cnergy equivalents from different sources. In this diet, a protcin-enriched, dry, milk powder is used as the protein source.

2. The diet was used in a two-group experiment lasting for $80 \mathrm{~d}$ in which the rats were fed ad lib. The consumption was $120 \mathrm{ml} / \mathrm{d}$ per rat in the control group, whereas in the ethanolconsuming group the consumpton was only $40 \mathrm{ml} / \mathrm{d}$ per rat at the start of the experiment and rose to and remained at $80 \mathrm{ml} / \mathrm{d}$ per rat after $20 \mathrm{~d}$.

3. The control group grew normally. In the ethanol-consuming group, there was an inital loss of body-weight; after $20 \mathrm{~d}$ there was some increase in body-weight but growth was slower than in the control group. The smaller food intake in the ethanol group was not wholly caused by the lower body-weight.

4. The free and total activities of acid phosphatase $\left(E C C_{3} . \tau_{3} .2\right)$ and $\beta$-glucuronidase (EC 3.2.1.31) were estimated in the liver after $10,20,30,40,60$ and $80 \mathrm{~d}$. Neither the free nor the total activity of acid phosphatase changed significantly during the experiment. The ratio of free activity to total activity increased significantly after $20-40 \mathrm{~d}$ of treatment with ethanol. The free and total activities of $\beta$-glucuronidase were significantly increased after ro $d$ of treatment with ethanol, but this difference could not be shown after prolonged treatment.
\end{abstract}

When ethanol is given in the drinking-fluid as a solution (100-1 $5 \circ \mathrm{ml} / 1$ ) rats will consume rather small amounts of ethanol, which are not sufficient to cause hepatic lesions, that is, the infiltration of fat, hepatitis and cirrhosis which can be found in alcoholics (Klatskin, Gewin \& Krehl, I95 I Germer \& Choi, 1959; Dajani, GhandurMnaymneh, Harrison \& Nassar, 1965; Jabbari, Baker \& Leevy, 1965; Saville \& Lieber, 1965 ). Giving rats an ethanol solution ( $5 \circ \mathrm{ml} / 1$ ) as their sole drinking fluid for several months will induce changes in the structure and function of the liver mitochondria, compared with controls given isoenergetic amounts of sucrose (Kiessling \& Pilström, I966a, b).

Lieber, Jones, Mendelson \& DeCarli (1963) have introduced the use of liquid diets as the only source of food and fluid. In this way, larger amounts of ethanol can be administered. This diet contained amino acids instead of protein, which made it expensive. Later, the amino acids were exchanged for casein with the addition of methionine and cysteine, and in this diet $18 \%$ of the energy intake was provided as protein (DeCarli \& Lieber, r966, r967). Through the courtesy of Dr C. S. Lieber, we were able to test this diet, but we had great difficulties in making the suspension stable and the casein always settled in the feeding tubes within a few hours. To avoid

* Parts of this investigation have been reported by Pilström, L., Fellenius, E., Berglund, I. and Kiessling, K.-H. in Proc. Nutr. Soc. (1972), 31, 36A. 
this, other sources of protein were tried and, after some experimentation, a semisynthetic liquid diet was produced with a protein-enriched, dry, milk powder as the source of protein. This diet was used for feeding rats with ethanol for $80 \mathrm{~d}$. Results are presented regarding food intake, growth and the activity of two lysosomal enzymes. As regards the formation of Mallory bodies (alcoholic hyaline), it has been suggested that these bodies arise from degenerated mitochondria and altered lysosomes (Flax \& Tisdale, 1964; Porta, Hartroft \& de la Iglesia, 1965). French (1968) found no alteration of acid phosphatase in suspensions of liver mitochondria after chronic ethanol ingestion. It has also been demonstrated that the lysosomal enzymes do not induce the fragility of liver mitochondria which is found after ethanol treatment (French $\&$ Morin, 1969).

However, it is not necessary that the total activity of lysosomal enzymes should be involved in the damage to the tissue caused by ethanol intake, although the relative proportion of free activity may be of importance. To study the effect of prolonged ethanol intake on the hepatic lysosomes, the free and total activities of acid phosphatase $\left(E C_{3} \cdot \mathrm{I}_{3} \cdot 2 \cdot 2\right)$ and $\beta$-glucuronidase $\left(E C_{3} \cdot 2 . \mathrm{I} \cdot 3 \mathrm{I}\right)$ have been measured. The main result was a significant increase in the ratio of free: total acid phosphatase.

\section{MATERIAL AND METHODS}

\section{Animals}

Male Wistar rats from the stock of this Institute were chosen in such a way that one control rat and one experimental rat forming a pair came from the same litter. The pairs were divided at random into six groups, which were given the liquid diets for different periods. Each group consisted of ten control and ten experimental animals and both were given the liquid diets for $10,20,30,40,60$ and $80 \mathrm{~d}$. The mean age of the rats at the beginning of the experiment was $5 \mathrm{r} \cdot 3$ (range 40-76) d; the mean bodyweight \pm SEM of the sixty control rats was $226 \pm 6 \mathrm{~g}$ and of the experimental group $232 \pm 6 \mathrm{~g}$.

The animals were kept in separate cages in a room without windows but automatically illuminated between 08.00 and 20.00 hours. The room temperature was kept constant at $25^{\circ}$. The rats were weighed once a week. The liquid diets were given in tubes (Fig. I) and $200 \mathrm{ml}$ were given to each rat each day. Before refilling the tubes on the following day, the consumption was estimated by means of a centimetre scale.

\section{Liquid diets}

In the diets 0.18 of the energy content was derived from protein, 0.37 from fat, and from carbohydrates 0.45 in the control diet and 0.075 in the ethanol diet. The latter derived 0.375 of its energy content from ethanol.

The ingredients were mixed in the amounts shown in Table $\mathbf{I}$ and homogenized in an Electro-Mischer Fortuna disintegrator (Heinz Gaebelt, Bremen) and the final liquid diet was stored at $4^{\circ}$. Diets stored for more than $3 \mathrm{~d}$ were discarded. Mostly the animals received freshly prepared or I-d-old diets. This was done to avoid bacterial or fungoid growth. 

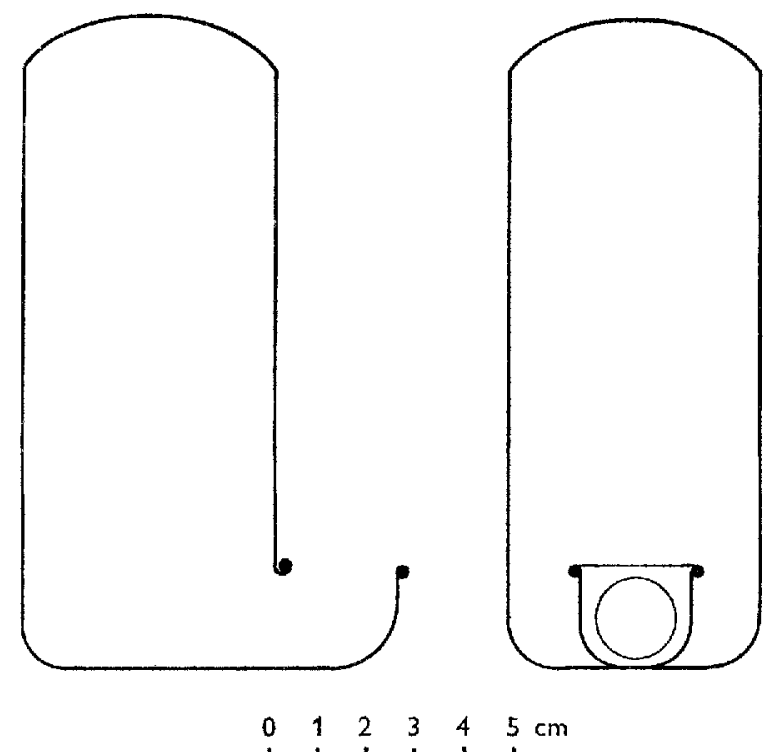

Fig. I. Tubes used for the supply of liquid diet to rats. The tubes were equipped with a centimetre scale for measuring the daily consumption.

Table I. Composition $(\mathrm{g} / \mathrm{l})$ of the control and ethanol-containing liquid diets

Ingredient

Dry milk powder (S. 67)*

Maize oil $\dagger$

Vegetable oil $\ddagger$

Sugar§

Ethanol

Vitamin mixture $\|$

Hegsted's salt mixture

Cystine

Methionine

Sodium carraginate (Viscarin) I

Vitamin A-D-E mixture**

Distilled water

\begin{tabular}{|c|c|}
\hline Control & containing \\
\hline $67-5$ & $67 \cdot 5$ \\
\hline $7^{\circ} 0$ & 7.0 \\
\hline $30 \cdot 0$ & $30 \cdot 0$ \\
\hline 103.0 & $12 \cdot 0$ \\
\hline 一 & 50.0 \\
\hline $5 \%$ & $5 \cdot 0$ \\
\hline 5.0 & $5^{\circ} \mathrm{O}$ \\
\hline 0.5 & 0.5 \\
\hline 0.2 & 0.2 \\
\hline$I \cdot O$ & $I \cdot O$ \\
\hline $1 \cdot 0$ & I'O \\
\hline To I 1 & To 1 \\
\hline
\end{tabular}

*Purchased from Semper AB, Stockholm; protein-enriched, containing $(\mathrm{g} / \mathrm{kg})$ : 67o milk protein, 200 milk sugars, ro fat, I 9 calcium, I 4 phosphorus, $x \cdot 5$ magnesium, 7 potassium, $4 \cdot 5$ sodium, $4 \cdot 5$ chloride, 29 unspecified minerals, and 40 water. The vitamin content was very low and was neglected in the formula of the final diet.

+ Manufactured by Deutsche Maizena Werke, Hamburg.

† Manufactured by Reymersholms Livsmedel, Eslöv, Sweden: contained $550 \mathrm{~g} / \mathrm{kg}$ polyunsaturated fatty acids (Kronolja).

$\S$ Ordinary granulated, purchased from Svenska Socker AB, Stockholm.

II Lieber \& DeCarli (1970).

- Generous gift from Marine Colloids Inc., Springfield, New Jersey, USA.

* Composed of $\mathrm{I} \cdot 75 \mathrm{mg}$ retinol, $0.01 \mathrm{mg}$ ergocalciferol, $30 \mathrm{mg} \alpha$-tocopheryl acetate and $970 \mathrm{mg}$ maize oil. 
No. of rats from which values were estimated
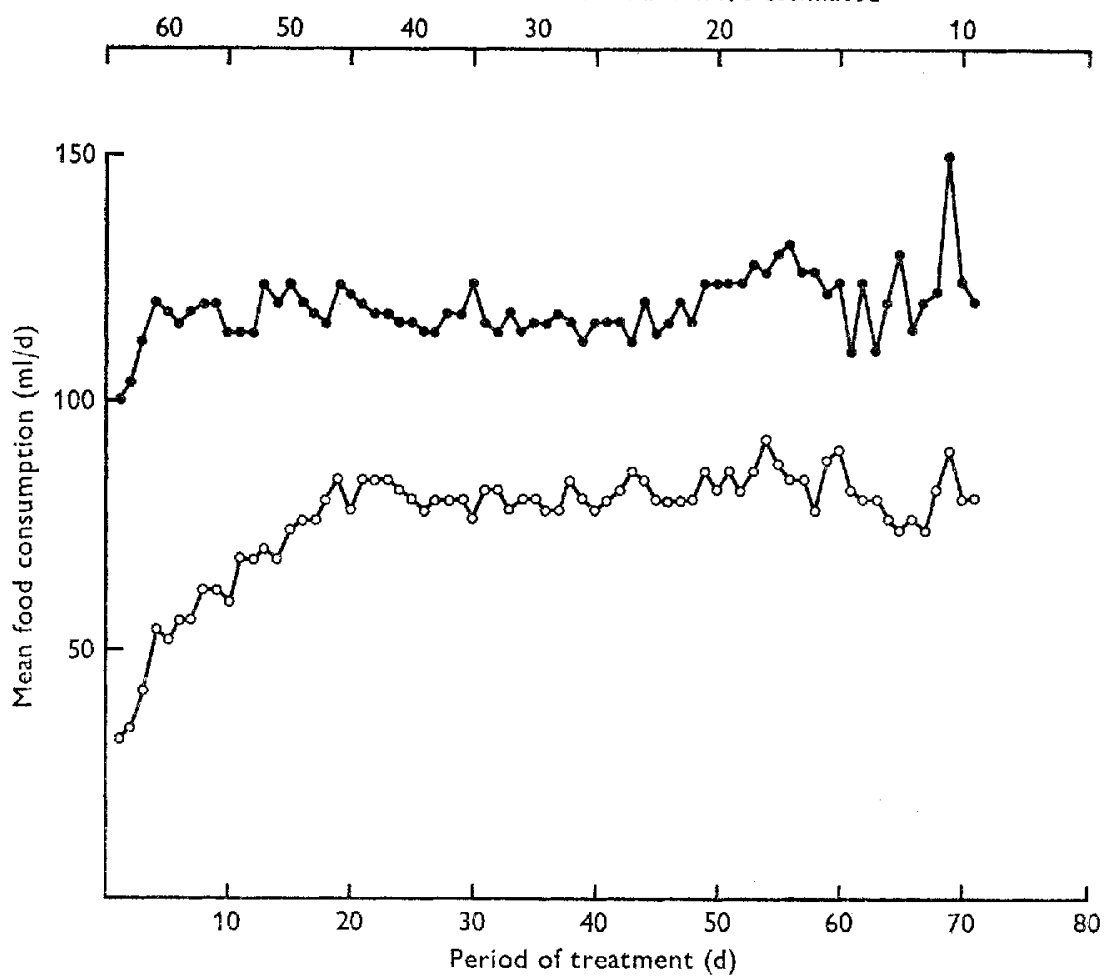

Fig. 2. Mean daily food intake by rats of a liquid diet containing ethanol (O) and of the control diet (O).

\section{Estimation of enzyme activities}

On the day of the experiment, the rats in each pair were killed by a blow on the neck and bled out. One lobe of the liver was removed and rapidly chilled in ice-cold $0.25 \mathrm{M}$-sucrose solution, sectioned and rinsed. The liver was gently homogenized for $60 \mathrm{~s}$ in $0.25 \mathrm{M}$-sucrose $(9 \mathrm{ml} / \mathrm{g}$ tissue) with a glass homogenizer and a teflon pestle. The homogenate was centrifuged for $5 \mathrm{~min}$ at $750 \mathrm{~g}_{\mathrm{av}}$. The supernatant fraction obtained was divided into two parts. Ten microlitres of a Triton (Sigma Chemical Co., Cleveland, Ohio, USA) solution ( $100 \mathrm{~g} / \mathrm{l}$ ) were added to each $\mathrm{ml}$ of one of the parts, which was labelled 'total activity'. The other untreated part was labelled 'free activity'.

The two solutions were centrifuged for $20 \mathrm{~min}$ at $75000 \mathrm{~g}_{\mathrm{av}}$ in a MSE ultracentrifuge, Type 40. The clear supernatant fractions were used for the estimation of enzyme activities. During the whole preparation procedure, the temperature was kept at $0-4^{\circ}$.

The activity of acid phosphatase was estimated by incubating $0.1 \mathrm{ml}$ of the supernatant fraction with $\mathrm{I} .5 \mathrm{ml}$ of $0 . \mathrm{I}$ M-acetate buffer, $\mathrm{pH} 5.0$, and $0.5 \mathrm{ml}$ of $0.02 \mathrm{M}-\mathrm{p}$ nitrophenylphosphate (Sigma Chemical Co.) for $10 \mathrm{~min}$ at $37^{\circ}$. The reaction was stopped by adding $5^{\circ} \mathrm{ml}$ of $0.08 \mathrm{M}$-sodium hydroxide. The extinction was measured at $430 \mathrm{~nm}$. 


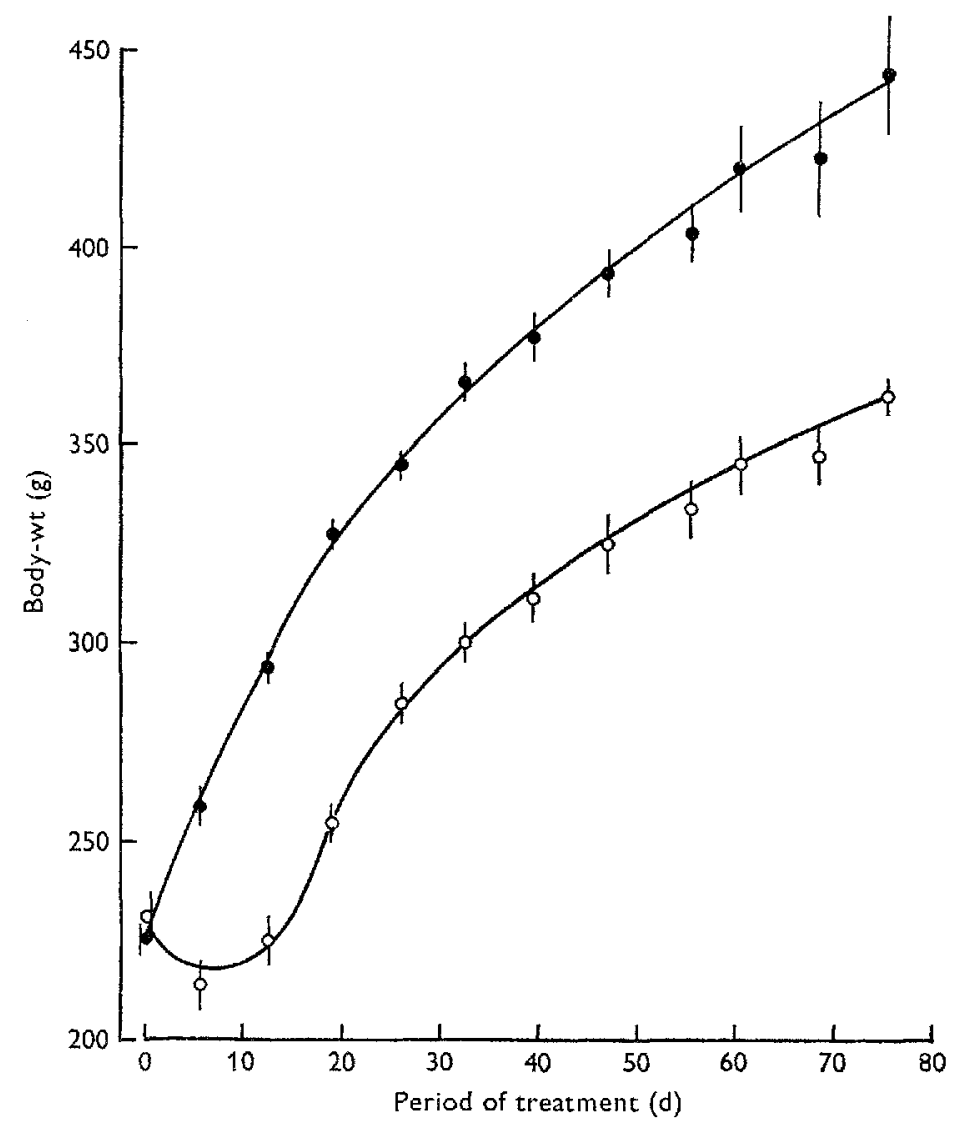

Fig. 3. Mean body-weights of rats fed on a liquid dict containing ethanol $(O)$ or on the control diet (O). The points represent mean values for sixty, fifty-nine, forty-six, forty-four, thirty, twenty, nineteen, sixteen, eight and fourteen pairs of rats for the period o- $80 \mathrm{~d}$; the vertical bars represent the standard errors of the mean.

To estimate the activity of $\beta$-glucuronidase, $O . I \mathrm{ml}$ of the supernatant fraction was incubated, together with $0.5 \mathrm{ml}$ of $0.1 \mathrm{M}$-acetate buffer, $\mathrm{pH} 5.0$, and $0.1 \mathrm{ml}$ of 0.0 I M-phenolphthalein- $\beta$-glucuronide (Sigma Chemical Co.) for 30 min at $37^{\circ}$. After addition of $2.0 \mathrm{ml}$ of $0.4 \mathrm{M}$-glycine buffer, $\mathrm{pH}{ }_{10} \cdot 7$, and centrifugation, the extinction was measured at $545 \mathrm{~nm}$.

The protein content of the supernatant fractions was determined by an indirect colorimetric method (Bramhall, Noack, Wu \& Locwenberg, 1969). The results were evaluated statistically by Student's $t$ test for paired groups.

\section{RESULTS}

Food intake and growth

As there was no pair-feeding, consumption was measured in the two groups. Initially, the control group consumed about $100 \mathrm{ml} / \mathrm{d}$ per rat, but by the $4^{\text {th }}$ day they had increased their food intake to $\mathrm{r} 20 \mathrm{ml}$. At this level consumption remained fairly 


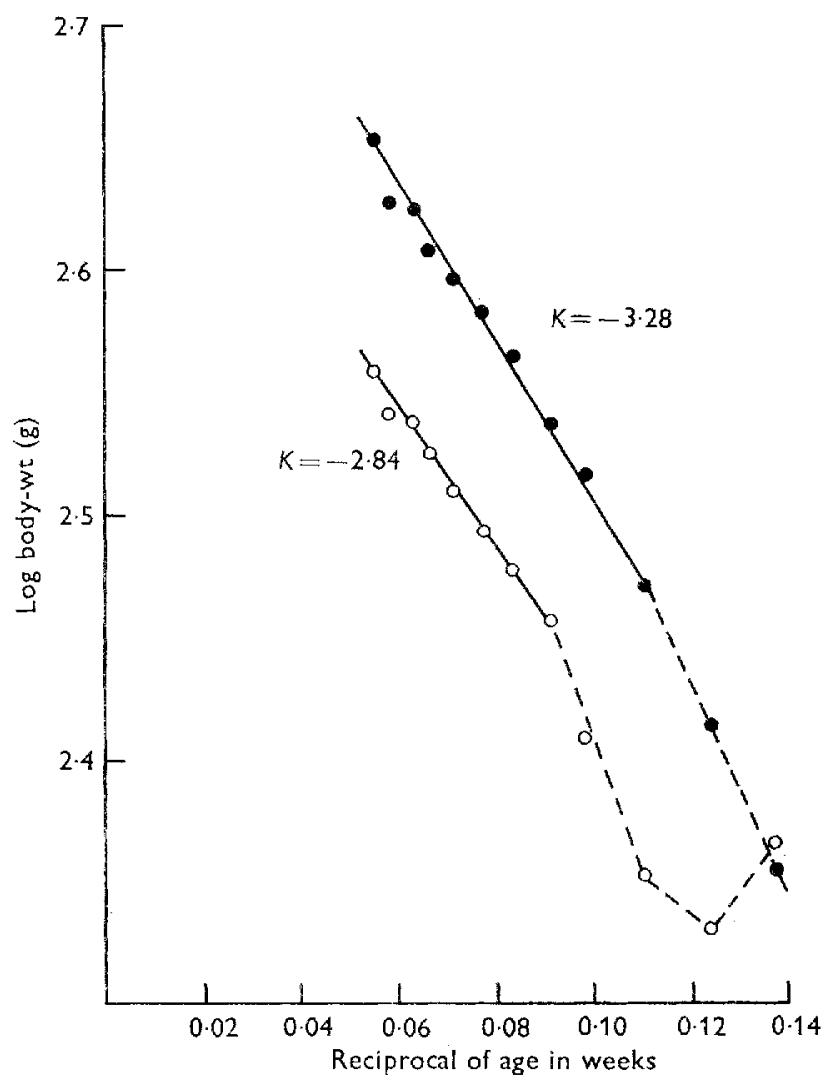

Fig. 4. Logarithm of body-weight plotted as a function of the reciprocal age for rats fed on a liquid diet containing ethanol $(O)$ or on the control diet $(-)$. The slope of the line $(K)$ is a measure of growth. For further details, see Zucker \& Zucker (I94I-2). Each point was estimated from the values shown in Fig. 3 .

constant throughout the experiment (Fig. 2). Within the ethanol-consuming group, the initial intake of the liquid diet was about $40 \mathrm{ml} / \mathrm{d}$ per rat. On the 10 th day the mean intake had increased to $60 \mathrm{ml}$, but not until the 20 th day did it reach $80 \mathrm{ml}$, the level at which it remained constant (Fig. 2).

The growth of the control group was normal (Fig. 3). As growth is not a linear function against time, Zucker \& Zucker (194I-2) have introduced the use of $K$-values as a measure of growth. $K$ is the slope of the line obtained when log body-weight is plotted as a function of reciprocal age. An estimation of $K$ for the control group yielded a value of -3.28 (Fig. 4) which is close to the value for normal rat populations (Zucker \& Zucker, I94I-2). In the ethanol-treated group, there was an initial loss of weight. After the 20 th day, the growth rate was lower (Fig. 3 ). The $K$-value for the ethanol-treated group was only $-2 \cdot 84$ (Fig. 4 ).

The lower body-weight in the ethanol-consuming group may have been the reason for the lower food intake in this group, compared with that of the control rats. However, a plot shows that the relative food consumption ( $\mathrm{ml} / \mathrm{d}$ per $\mathrm{kg}$ body-weight) was lower in the ethanol group (Fig. 5). 


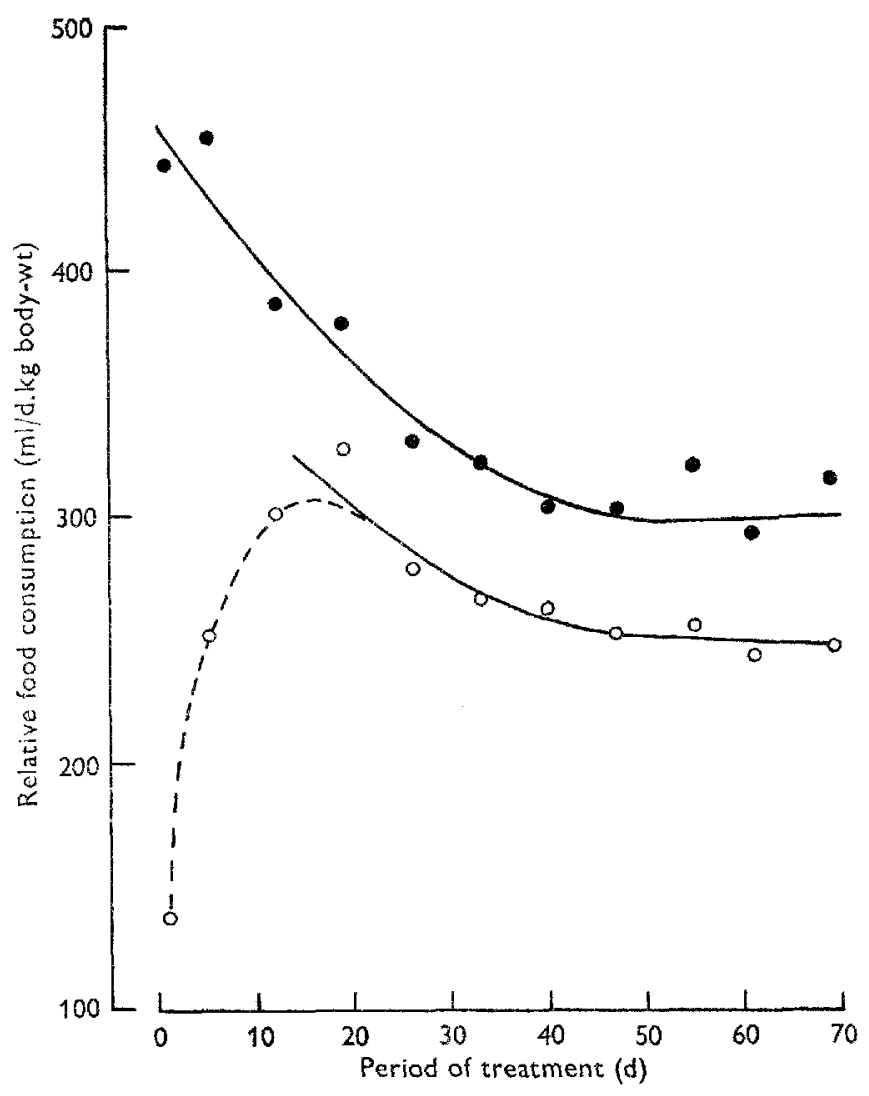

Fig. 5. Daily food consumption relative to body-weight of rats fed on a liquid diet containing ethanol (O) or on the control diet (O). The values were estimated from the values in Figs 2 and 3 .

\section{Activities of lysosomal enzymes}

The total activity of acid phosphatase was somewhat lower in the ethanol group than in the controls after 20,30 and $40 \mathrm{~d}$, and free activity was a little greater during the whole experiment (Fig. 6a). These differences were, however, not statistically significant $(p>0.05)$. Estimation of the relative free activity (the free activity as a percentage of the total activity) showed a statistically significant increase after 20 , 30 and $40 \mathrm{~d}$ in the ethanol-treated group (Fig. $7 a$ ).

The total and free activities of $\beta$-glucuronidase were significantly greater in the ethanol group than in the controls after 1o d. This difference gradually disappeared, and after $20 \mathrm{~d}$ both activities remained nearly equal in the two groups during the rest of the experiment (Fig. $6 b$ ). The relative free activity of $\beta$-glucuronidase showed no alteration in the ethanol group, compared with the control group (Fig. $7^{b}$ ). 


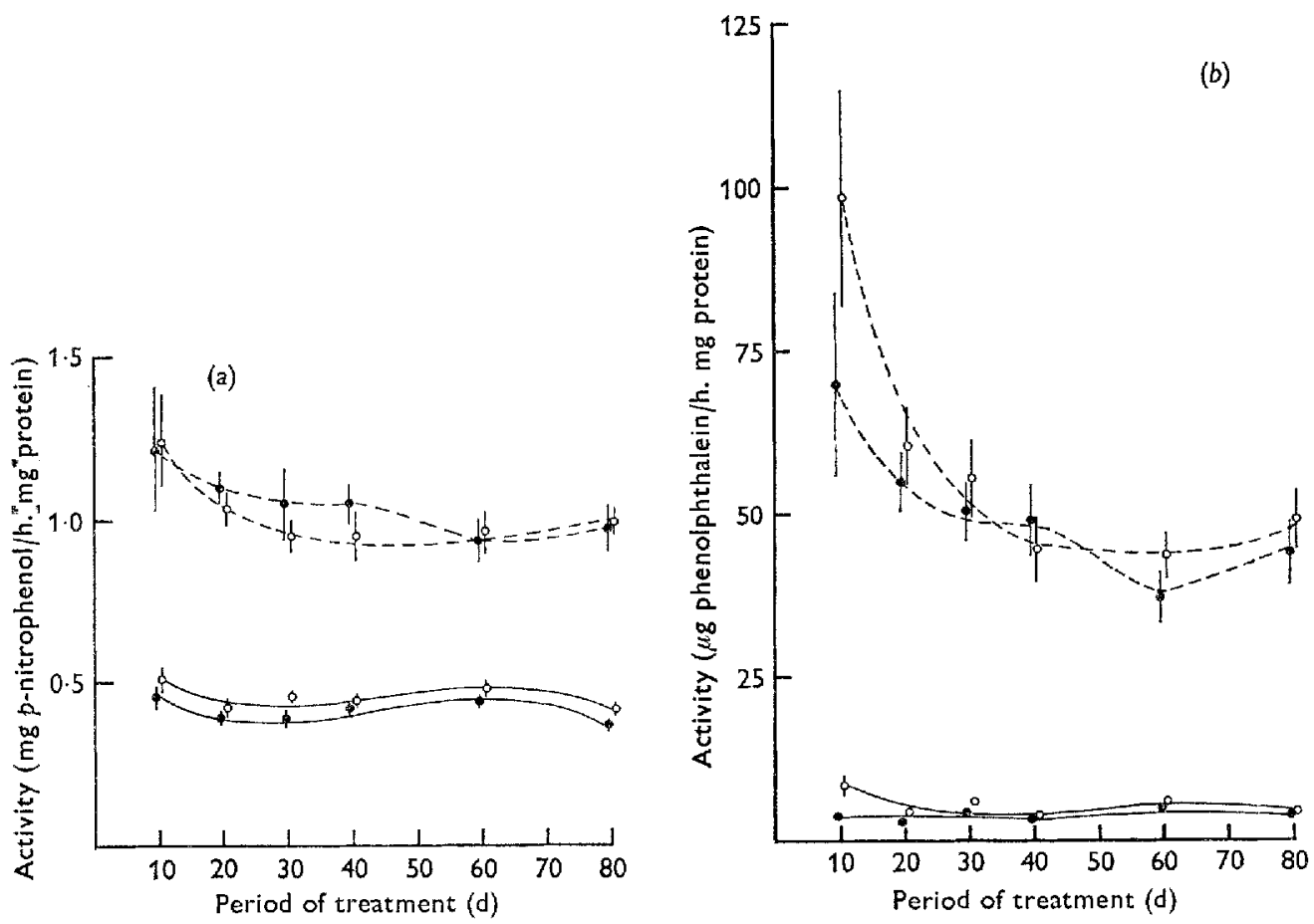

Fig. 6. Total (--) and free (-) activities of acid phosphatase $(a)$ and $\beta$-glucuronidase (b) in the liver of rats fed on a semi-synthetic liquid diet containing ethanol $(O)$ or on the control diet (O). Each point represents a mean value for ten animals; the vertical bars represent the standard errors of the mean. In $(b)$, after $10 \mathrm{~d}$ of treatment, the differences between treated and control rats for both the total and free activities were statistically significant $(P<0.001)$.
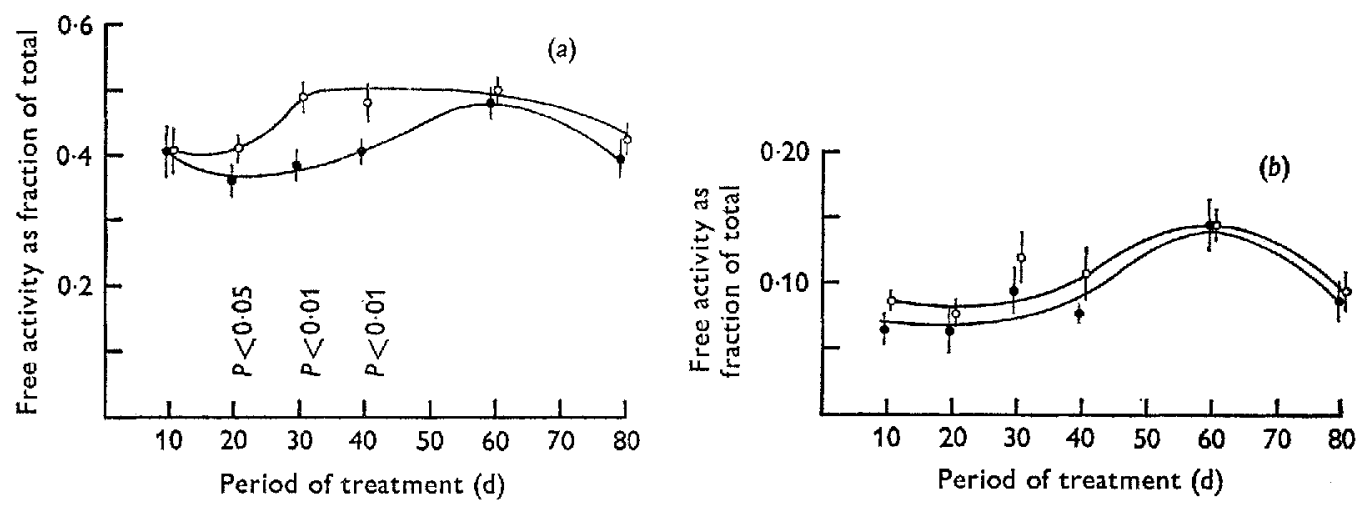

Fig. 7. Free activities of acid phosphatase $(a)$ and $\beta$-glucuronidase $(b)$ as fractions of the total activity in the liver of rats fed on a liquid diet containing ethanol (O) or on the control diet (๑). Mean values for ten animals; the vertical bars represent the standard errors of the mean. 
DISCUSSION

\section{Diet, food intake and growth}

Since the introduction of liquid diets for the supply of ethanol, several authors have described the use of such diets (Lieber et al. 1963; Porta et al. 1965; Jones \& Grcene, I966; Hartman \& Di Luzio, I968; Zakim \& Green, I968; Oudea, Launay, Quénéhervé \& Oudea, 1970). However, none of these authors has reported any difficulties with the stability. When we tried the diet with casein as the protein source, as described by DeCarli \& Lieber (1966, r967), we found a rapid sedimentation, which caused obstruction of the feeding tubes. To avoid this difficulty, dry milk powders were tried, which should yield more stable solutions. Ordinary dry milk has unsuitable proportions of its main constituents, that is protein, fat and carbohydrates. Besides, the vitamin content is not sufficiently constant enough to permit its use in nutritional studies. However, with the protein-enriched, dry, milk powder called S. 67 , these difficulties were overcome.

The growth of the rats fed with liquid control diet was normal and, after an initial loss in body-weight, growth was slower but fairly normal in the ethanol-consuming group (Figs 3 and 4). This was in contrast to the results of Oudea et al. (1970), who found a continuous decrease in body-weight and an increased death rate when rats were given ethanol in a liquid diet. In our experiment in which rats were fed for up to $80 \mathrm{~d}$ with a liquid ethanol diet, all the rats survived and none lost weight to an extent greater than that shown in Fig. 3. The composition of our diet did not vary much from that reported by Oudea et al. (1970).

Both absolute food consumption and food consumption relative to body-weight were lower in the ethanol group than in the control group (Figs 2 and 5), which indicates that a pair-feeding technique should be used in order to obtain similar nutrition in the two groups.

\section{Lysosomal enzyme actioities}

Several drugs of different kinds are known to produce effects on the lysosomal enzyme activities both in vivo and in vitro (Slater, 1969; Weissman, 1969). An effect on the lysosomal enzymes in the liver could also be expected after long-term ethanol ingestion, which is known to produce fatty liver, hepatic cell necrosis and hepatitis, which may be followed by fibrosis (Klatskin et al. I951; Germer \& Choi, I959; Dajani et al. 1965; Jabbari et al. 1965; Saville \& Lieber, 1965). As can be seen in Figs 6 and 7 , there were no major alterations in the total and free activities of acid phosphatase or $\beta$-glucuronidase in the rat liver, even when 0.37 of the energy intake was derived from ethanol for $80 \mathrm{~d}$. This is in agreement with the results of French (1968), who found no alterations in the activity of acid phosphatase in the mitochondrial fraction from the livers of rats given more than one-third of their energy intake in the form of ethanol for several months.

Thus, it seems reasonable to conclude that the lysosomes and their enzymes are unaffected by ethanol consumption. As the rate of development of hepatic injuries which give rise to cirrhosis are probably caused by several factors, for example nutritional deficiencies (Porta, Koch \& Hartroft, I969; Gros, I97I) and the way of drinking 
(Wallgren, Ahlqvist, Ahman \& Suomalainen, 1967), we may be more likely to find alterations of the lysosomes in these conditions.

The increased activity of $\beta$-glucuronidase found after $10 \mathrm{~d}$ of treatment with ethanol (Fig. 6) cannot be explained satisfactorily. It has been observed that fasting increases the total and free activities of $\beta$-glucuronidase in the liver (Filkins, 1970). After ro d the food consumption of the ethanol group was low in our experiments (Fig. 2). However, this cannot be the whole explanation, as acid phosphatase seems to be more sensitive than $\beta$-glucuronidase to fasting (Filkins, 1970 ), and the free and total activities of acid phosphatase were unchanged in the ethanol group, compared with those in the control group (Fig. 6). Fasting also changes the fraction of free activity of the two enzymes and again acid phosphatase is more sensitive. A significant increase in the fraction of free activity of acid phosphatase was found after 20,30 and $40 \mathrm{~d}$, and an insignificant increase of $\beta$-glucuronidase after $10,20,30$ and $40 \mathrm{~d}$ in the ethanol group (Fig. 7). Thus, these increases may have been caused by the lower food consumption of the ethanol group. If this is true, the 'normalization' after 60 and $80 \mathrm{~d}$ may be some kind of adaptation to the new conditions.

We are indebted to Miss Inger Berglund and Mr Kjell Lindbäck for skilful technical assistance. This investigation was made possible by grants from the Lars Hiertas Minne Foundation and from the Swedish Medical Research Council (Project No. B7I-r $3 \mathrm{X}-575-07 \mathrm{C}$ ).

\section{REFEREN CES}

Bramhall, S., Noack, N., Wu, M. \& Loewenberg, J. R. (1969). Analyt. Biochem. 31, 146.

Dajani, R. M., Ghandur-Mnaymneh, L., Harrison, M. \& Nassar, T. (1965). \%. Nutr. 86, 29.

DeCarli, L. M. \& Lieber, C. S. (I966). Fedn Proc. Fedn Am. Socs exp. Biol. 25, 304.

DeCarli, L. M. \& Lieber, C. S. (1967). F. Nutr. 9r, 331.

Filkins, J. P. (1970). Am. F. Physiol. 2r9, 923.

Flax, M. H. \& Tisdale, W. A. (1964). Am. F. Path. 44, 44r.

French, S. W. (1968). Gastroenterology 54, 1106.

French, S. W. \& Morin, R. J. (1969). In Biochemical and Clinical Aspects of Alcohol Metabolism p. 123 [V. M. Sardesai, editor]. Springfield, Ill: C. C. Thomas.

Germer, W. D. \& Choi, H. (1959). Z. Ges. exp. Med. 131, 238.

Gros, H. (197I). In Alcohol and the Liver, International Symposium, 2-4 Oct. 1970, Freiburg p. 353

[W. Gerok, K. Sickinger and H. H. Hennekeuser, editors]. Stuttgart: F. K. Schattauer Verlag.

Hartman, A. D. \& Di Luzio, N. R. (1968). Proc. Soc. exp. Biol. Med, 127, 270.

Jabbari, M., Baker, H. \& Leevy, C. M. (1965). Am. 7. clin. Nutr. 16, 382.

Jones, D. P. \& Greene, E. A. (1966). Am. F. clin. Nutr. 18, 350.

Kiessling, K.-H. \& Pilström, L. (1966a). Q. Fl Stud. Alcohol 27, 189 .

Kiessling, K.-H. \& Pilström, L. (I966b). Acta pharmac. tox. 24, 103.

Klatskin, G., Gewin, H. M. \& Krehl, W. A. (I95I). Yale F. Biol. Med. 23, 3 17.

Lieber, C. S. \& DeCarli, L. M. (1970). Am. F. clin. Nutr. 23, 474.

Lieber, C. S., Jones, D. P., Mendelson, J. \& DeCarli, L. M. (1963). Trans. Ass. Am. Physns 76, 289.

Oudea, M. C., Launay, A. N., Quénéhervé, S. \& Oudea, P. (1970). Rev. eur. Étud. clin. biol. 15, 748.

Porta, E. A., Hartroft, W. S. \& de la Iglesia, F. A. (1965). Lab. Invest. 14, r 437.

Porta, E. A., Koch, O. R. \& Hartroft, W. S. (1969). Fedn Proc. Fedn Am. Socs exp. Biol. $28,626$.

Saville, P. D. \& Lieber, C. S. (1965). F. Nutr. 87, 477.

Slater, T. F. (1 969). In Lysosomes in Biology and Pathology Vol. I, p. 467 [J. T. Dingle and B. Fell, editors]. Amsterdam: North-Holland Publ. Co.

Wallgren, H., Ahlqvist, J., Ahman, K. \& Suomalainen, H. (1967). Br. F. Nutr. 21, 643.

Weissman, G. (1969). In Lysosomes in Biology and Pathology Vol. 1, p. 276 [J. T. Dingle and B. Fell, editors]. Amsterdam: North-Holland Publ. Co.

Zakim, D. \& Green, J. (1968). Proc. Soc. exp. Biol. Med. 127, 138.

Zucker, L. \& Zucker, T. F. (1941-2). F. gen. Physiol. 25, 445. 